\title{
From the Editor-in-Chief: Scopus Inclusion and EWJUS Translation Project
}

\author{
Svitlana (Lana) Krys
}

MacEwan University

$\mathbf{T}$ he current issue of East/West: Journal of Ukrainian Studies is one of the most diverse in terms of content. It opens with two critical fora: one concerns the Intermarium and security in the Black Sea region and is guest edited by Volodymyr Kravchenko of the Canadian Institute of Ukrainian Studies (CIUS) at the University of Alberta; the other takes the reader though early modern Ukraine and is guest edited by Giovanna Brogi of the University of Milan. Four regular articles that follow discuss the Canada-Ukraine free trade agreement, English proficiency in the adaptation of Ukrainian immigrant youth in Saskatchewan, translation practices of imprisoned Ukrainian literati in Soviet labour camps, and populism on Ukrainian television political talk shows ahead of the Ukrainian presidential election in 2019. There is also a research report on an automation project for adding Cyrillic fields to Ukrainian records in OCLC WorldCat, and the translation of an essay that creatively reflects on the music of American singer Norah Jones within the Ukrainian cultural context. Finally, the issue features an array of reviews of recent titles in Ukrainian studies.

Future publications of EWJUS will include thematic issues dedicated to (i) contemporary cultural responses to the ongoing Russo-Ukrainian war in Ukraine's east and (ii) the city of Odesa (a companion volume to EWJUS's recent issue on Kharkiv).

I am pleased to announce that EWJUS has been accepted into Scopus. The Scopus Content Selection \& Advisory Board (CSAB) reviewed EWJUS's application and approved it for coverage, effective 1 September 2021. In the words of Scopus's anonymous reviewers, "This is a well organised journal publishing material likely to interest SCOPUS users ... Much of the content impresses ... . [and] [t] he journal consistently includes articles that are academically sound and relevant to an international academic or professional audience in the field." I am proud of this acceptance as it has been one of the projects that I set for EWJUS, as its editor-in-chief. To reach this goal, several policies were developed for EWJUS that high-impact indices, such as Scopus or Web of Science, require of journals. These policies include statements on anti-plagiarism and research publication ethics, on research 
misconduct and retraction, and on digital archiving. They can be accessed on EWJUS's updated "About the Journal" page, along with our newly developed special issue policy. The download statistics are also now available for all publications on the EWJUS site.

The Scopus acceptance notice comes one year after another important milestone for EWJUS-an agreement with Coalition Publica/Érudit, a Canadian not-for-profit academic platform that also indexes EWJUS. Other databases where EWJUS is listed include the Directory of Open Access Journals, the MLA Directory of Periodicals, and EBSCO and ProQuestpartnered databases. Such broad indexing provides visibility and searchability to EWJUS issues.

I am happy to share another important news for this year-the launch of the English-Ukrainian translation project, thanks to which EWJUS publications will now be available in Ukrainian. The translation of articles from vol. 7.2 (the most recent issue at the time of the launch of the project) are featured in a separate section on the EWJUS website. These-and all future translations-will also be accessible alongside the original articles in the table of contents of relevant volumes. I hope these Ukrainian translations will make a positive impact on scholarship in Ukraine, strengthen the dialogue between scholars in Ukraine and scholars in Anglophone countries, and increase EWJUS's international readership.

EWJUS's translation project is made possible thanks to the academic cooperation with the MA translation program at the Taras Shevchenko National University of Kyiv. This co-operation enables EWJUS to offer senior graduate students in the program internship opportunities for a capstone project in academic translation. The Ukrainian side of the project is headed by Drs. Lada Kolomiyets and Olena Pidhrushna. I am extremely grateful to them for making this project happen and to student translators for their diligent work! I was impressed with students' professionalism, expertise, and meticulousness in translating articles that ranged from early modern to contemporary periods and involved complicated theoretical frameworks.

The publication of this volume (vol. 8, no. 2, fall 2021) was made possible by the generous support of the Anna and Nikander Bukowsky Endowment Fund at the Canadian Institute of Ukrainian Studies. I am grateful to the guest editors of two critical fora, our book review editor Tania Stech (CIUS, Toronto Office), our two copyeditors, Marcia Craig (Edmonton, AB) and Ksenia Maryniak (CIUS), our editorial assistants Cossette Massa and Emily Simon (MacEwan University), and Halyna Klid (CIUS) who designed the EWJUS cover. An open access platform provides EWJUS issues to readers free of charge, so please share our publications with colleagues and interested parties!

October 12, 2021 